\title{
LX.-NOTES AND CORRESPONDENCE.
}

\author{
THE IANERVATIONSEHPFINDUEG IN WUNDT'B PBYCHOLOGY.
}

I HAVB had occasion, in notices of several recent books, to call attention to what seemed to be 4 misunderstanding of Wundt's present position as regards the "feeling of effort". It may not be amise, therefore, to put together Wundt's wost recent atterances on the point; since the question of the existence of the sensation of innervation proper, more or less fallen out of discussion in psychology, has lately been brought into prominence again on the neurological side.

In the Phys. Prych. (8te Aufl., 1887, i 408) the sensation of movement is said to be probably the resultant of the fusion of three different factors: pressnre-sensations (from the skin and subcutaneous parts), unuscular (contraction) sensations and central innervation-sensations. Of these sensational components probably only two are in origin qualitatively distinguishable : the sensations of pressure and of contraction : while the sensations of innervation are nothing else than centrally excited gensations of movement-that is to say, the sensation of movement is made up of a fusion of skin-sensations and muscular-sensations with the reproductions of such fusions, previously experienced; the innervation-sensation is the reprodnction of a fusion of pressure- and contraction-sensations.

On p. 408 the same position is represented in more detail. It is stated as probable that "the sensations of innervation stand to the nuscalar [contraction] sensations in the relation in which in other sense-depart. ments the central excitations, aroused by memory-images, stand to the sensations which are caused by direct external stimulation affecting the whole of the special sensory apparatus". Theronly difference is this difference in the direction of stimulation: in the one case it is centripetal, in the other centrifugal.

It is in these passages that the nature of the " sensation of innervation" is discussed; and in their light must such phrases as " sensations which accompany the central act of volition" (i. 42) be interpreted. (Cf., e.g., 32, 38.)

Still more decisive is the statement in the essay, "Zur Lehre von den Gemüthsbewegungen" (Phil. Stitulien, 1891, vi. pp. $885 \mathrm{ff}$.). It is here given as Munsterberg's view (pp. 887,888 ) that "the so-called sensations of innervation, which can be observed in cases where no actnal movement takes place, are memory-images of sensations of movement previously experienced". Prof. Wundt writes: "This view of the sensations of innersation I regard as correct: I believe it to be the only one possible, in face of the recently published discussions of the subject. But it is a view which is by no means new. I have myself developed it at length in the third edition of my Phys. Psych. ...."

Finally, in the Vorlesungen ibber $d$. Mensechen n. Thier-Leeb (2te Aufl., $1892, p .147$ ) we find the sentence: "The sensations of muscular effort which are the invariable concomitants of acts of volition may be regarded as reproduced muscular [contraction] sensations ..."." In this passage the expression " sensation of innervation" does not occur. It may, however, very well be retained for the memorial representations of the particular sensations or sensation-fusions in question, which have for conscionsness such a peculiar value. That one should talk of a memory-image as a sensation is in accordance with Wundtian terminology in general. 
I hope that before this array of evidence the sentences beginning "Bain, Wundt and others . . ." will gradually disappear.

\section{E. B. Titchener.}

\section{To the EDIToR of MIND.}

Draz Sir, -Mr. Ward, in his orer-generous notice of my briefer Pyychology in your October number, says something which calls for a word of correction from me, for it concerns others besides myself. Quoting my sentence that mediamistic phenomena "ure a field which the wi-disant scientist usually refuses to explore," he names the Society for Psychical Hesearch, and remarks that it must strike the inpartial apectator as a little humorous that " these people " should not only have arrogated to thenselves a title under which every psychological inquirer might be enrolled, but should "stigmatise as soi-disant acientists the great body of paychologists, who, in fact, think proper not to join their ranks". If there is anything humorous here, it would seem to be the ascription to all "these people" of an opinion which was foreign even to the mind of the solitary author of the sentence from which Mr. Ward 80 ingeniously distils it, for no mention of the "S. P. R." was made in niy tert. The point is, as Mr. Ward says, a trifle, but exactitude is ineritorious; and I therefore beg to say that I have never heard one of " these people" brand any psychologist as a si-dieant scientist, or otherwise speak harshly of him for not joining the ranks of the society in question. 'The temper of the psyclical researchers is, as a rule, more hunble. As for myself (it I can remember what $\mathrm{xas}$ in wy mind when I wrote the sentence in point) the soi-disant scientists intended must have been such tine old crusted enemies of superstition as that eminent biologist who once said to me that if the facts of telepathy, ac., were true, the first duty which every honest man would owe to Science would be to deny them, and prevent them, if possible, from ever becoming known. I surely never dreamed, when I wrote the words "soi-disant scientist," of the numerous paychologienl inquirers who have not joined the "S. P. R." ; and least of all of such a truly scientific psychologist as Mr. Ward himself.

I remain, very truly yours,

Florence, Uctober $24,1892$.

WiLLLAX JahEs.

I am sony I have misunderstood Prot. Jannes. That I did it without " ingenuity" " $n$ word or two will show. First I "named" the S. P. R., and it is true they are not named in the text. But they are mentioned in a note appended to the very entence I quoted, and it is certain they occupy the field into which Prof. Jaines hopes to draw his psychological readers. Nert this is "the field which the soi-dieant scientist usually refuses to oxplore". Here somebody is blamed for not doing something which it is assumed he ought to do. Who is it? Do physicians reproach philologists for ignoring the conmu-bacillus? If psychical research is neglected. do we expect to find biologists called to task and not rather psychologists: and that when the censor is a psychologist writing about psychology? Lastly, if it was natural to suppose that psycliologists were intended, was there much straining in taking "usually" to imply" "the great body of psychologists," when it is notorious that the great body of psychologists are not, in fact, "psychical researchers"?

Cambridge, Dec. 11, 189-2.

JAYES WABD. 